\title{
Utilization of Annual Warm-Season Grasses as a Biofuel Source and Feedstock By-Product
}

\author{
Joshua A. White, Rocky Lemus \\ Department of Plant and Soil Sciences, Mississippi State University, Starkville, USA \\ Email: jwhite@pss.msstate.edu
}

Received 3 August 2014; revised 18 September 2014; accepted 20 October 2014

Copyright (C) 2014 by authors and Scientific Research Publishing Inc.

This work is licensed under the Creative Commons Attribution International License (CC BY). http://creativecommons.org/licenses/by/4.0/

(c) (i) Open Access

\begin{abstract}
Annual warm-season grasses such as forage sorghum, sorghum $\times$ sudangrass hybrid and sundangrass are highly productive and valuable feed crops (rotational crop and silage). In addition, sugar in the stems of these warm-season grasses can be extracted and fermented, while the cellulose in the bagasse (pressed stalk) can be used for feedstock or cellulosic ethanol, making them versatile to both the forage and biofuel industry. Twelve annual warm-season grasses including forage sorghums, sudangrass, sorghum $\times$ sudangrass hybrid, and pearl millet were planted in $1.82 \mathrm{~m} \times$ $3.35 \mathrm{~m}$ plots, harvested and treated as silage and hay before and after sap removal. Dry matter (DM) yield from a single harvest in 2011 and 2012 were collected and analyzed. Further analysis from the varieties includes evaluation for sap production, ${ }^{\circ} \mathrm{Brix}$, crude protein (CP), Neutral Detergent Fiber (NDF), and Acid Detergent Fiber (ADF). Forage quality in silage was negatively affected by removing the sap before ensiling, producing quality similar to that of the hay samples. Sugar yields (SY) were not comparable to sweet sorghum yields reported in the literature, but when considering SY along with bagasse yield a few varieties may offer the potential as a dual purpose crop.
\end{abstract}

\section{Keywords}

Bioenergy, Sorghum, Dual Purpose Crop, Ethanol from Sorghum Sap

\section{Introduction}

Bioenergy feedstock production today, is focused mainly on large operations geared soley toward biomass for bioenergy production. Little efforts are made to include options for forage growers seeking only to include bio- 
energy into an existing forage system without the adoption of an entirely new system that includes propagation of species like switchgrass (Panicumvirgatum) and giant miscanthus (Miscanthus spp.). It is uncommon to find data that compare those systems against the possible forage value. Without such data, a producer would not likely adopt any practices to include bioenergy crop alternatives. As agriculture strides forward as the main feedstock supplier of bioenergy, it will be essential to include options for many types of producers by focusing on dual-purpose crops. One possibility gaining popularity is the use of high sugar summer annual crops as silage and as a supplier of sap for eventual ethanol production. Crop species for these systems include pearl millet (Pennisetum glaucum), forage sorghum (Sorghum bicolor), sudangrass and sorghum-sudangrass hybrids (Sorghum $\times$ drummondii).

\section{Sorghum Crops as Bioenergy Feedstocks}

\subsection{Sap Production}

Sap of most sorghums is mainly sucrose which can be easily fermented for ethanol production without any pretreatment. Related literature considering the use of sorghums for ethanol, focuses on the utilization of the entire plant (cellulose and hemicelluloses) for eventual fermentation. However, this involves a pretreatment of the whole plant and usually considers BMR varieties with lower lignin content [1]. Other trials utilized sweet sorghum varieties common in syrup production, for sap removal with the bagasse (residual biomass) being alternatively converted to energy via co-firing or further enzymatic treatment [2]. Sweet sorghum varieties are most commonly considered for sap production as they have been intensely selected for sugar production; but have little forage yield. The sap does not require energy to depolymerize carbohydrates [3] and can produce sugar yields ranging from 5 - 10 metric tons ha $^{-1}$ [4]. From sweet sorghum sap alone ethanol yields range from 3000 - 4000 $\mathrm{L} \cdot \mathrm{ha}^{-1}[5]$. A recent assessment of the feasibility of sweet sorghum as an ethanol feedstock in Mississippi concluded that it would be unprofitable [6]. However, the assessment assumed that sweet sorghum biomass was the only product produced thus demanding that profit be wholly returned through ethanol production. The study also assumed competing crops to be corn, cotton, and soybeans commonly grown in the two counties assessed. Though it has been shown that sweet sorghum may not work as a feedstock for ethanol in Mississippi, especially when displacing high value row crops, by product sap production from forage cultivars by beef or dairy producers may assess differently.

\subsection{Bagasse of Sorghum}

Bagasse is generally described as the residual biomass after the sap has been removed from the product. Sorghum bagasse has the potential to be further utilized for ethanol production [7] or as a feedstock for livestock [8]. Some of the most recent data in lignocellulose conversion report forage sorghum and sweet sorghum bagasse to yield $17.1 \mathrm{~g}$ and $15.9 \mathrm{~g}$ respectively of ethanol per $100 \mathrm{~g}$ of biomass [7]. Alternatively, sorghum bagasse can be utilized as livestock feed similarly to what is implemented in Brazil with sugarcane [9]. However, bagasse from sweet sorghum managed for sugar content rather than forage production can be lower in digestibility sometimes requiring biomass to be ammoniated to increase feed value [8]. While ammoniation was found to increase crude protein levels, an increase in digestibility was inconsistent at all locations and across all varieties, with some varieties providing better fiber digestibility before treatment. This suggest that some varieties or even species may provide a higher quality bagasse that may not require further processing before utilization as livestock feed. With the exception of sugarcane and sweet sorghum little is known about feed quality of bagasse from other warm season annual grasses.

\subsection{Sorghum, Millet, and Sudangrass Forage Yield Potential}

Although millets, sorghums and sudangrass only encompass a small percentage of hectares in Mississippi (25,000 ha) [10], variety trials have shown that acceptable yields can be obtained. Variety trials in Mississippi have reported millet annual DM yields of $8519 \mathrm{~kg} \cdot \mathrm{ha}^{-1}$ and sorghum-sudangrass yields of $6422 \mathrm{~kg} \cdot \mathrm{ha}^{-1}$ [11]. More recent trials in south Mississippi have demonstrated sorghum yields up to 11 metric tons $\cdot \mathrm{ha}^{-1}$ [12]. Genetic improvements have also been made to pearl millet varieties, which have led to yields over $9000 \mathrm{~kg} \cdot \mathrm{ha}^{-1}$ in Mississippi [12]. Due to the high moisture content and digestibility of these grasses, they are most commonly uti- 
lized as silage or greenchop with the exception of some sudangrass varieties that can be utilized as hay. These species perform best when sown conventionally increasing the energy needed for establishment. In contrast, bermudagrass (Cynodondactylon) and bahiagrass (Paspalumnotatum) are perennial grasses that do not require replanting every year and are commonly used by cattle producers in the state. However, similar dry matter yields [12] and better fiber quality can be obtained with summer annuals with less nitrogen input. Forage yields have been well documented, but relatively little is known about the sap production of these sugar rich crops.

Research is relatively limited on the use of warm-season annual forage crop as a dual purpose bioenergy and forage provider. The objective of this trial was to evaluate the performance of several varieties of annual warm-season grasses with high sugar content as dual purpose crops for simultaneous ethanol and silage production.

\section{Materials and Methods}

\subsection{Location, Harvest, and Treatments}

The study was conducted in Starkville, Mississippi at the Henry H. Leveck Animal Research Farm $\left(33^{\circ} 25^{\prime}\right.$ 53.07"N, 88 $47^{\prime} 11.15^{\prime \prime}$ ) in a Marietta fine sandy loam during the 2011 and 2012 growing season. The experimental design was a randomized complete block, replicated four times. The study was conducted using 12 annual warm-season grasses which included forage sorghums, sudangrass, sorghum $\times$ sudangrass hybrid and pearl millet. All plots were planted at a seeding rate of $28 \mathrm{~kg} \cdot \mathrm{ha}^{-1}$ in a $1.82 \mathrm{~m} \times 3.35 \mathrm{~m}$ plot. Planting date for 2011 was June 16 while 2012 was planted on 5 May 2011. Rainfall was variable between years as described in Figure 1. Plots were harvested when $50 \%$ of the total plots reached the boot stage. Plots were fertilized with $56 \mathrm{~kg} \mathrm{~N}$ $\mathrm{ha}^{-1}$ using urea ammonium sulfate. Prior to harvest, plant population measurements were taken using two $1 \mathrm{~m}^{2}$ quadrants placed sequentially in the middle of each plot. Eight stalks were randomly cut at a height of $7.5 \mathrm{~cm}$ from the ground for sap extraction; fresh weight (including leaves and stems) was recorded. Sap was extracted from 4 whole plants using a sugar cane press and sap weight, volume and Brix $\left({ }^{\mathrm{O}} \mathrm{Bx}\right)$ were recorded. Percent Brix was measured using a VEE GEE refractometer model PDX-1 (VEEGEE Scientific, Kirkland, WA). Estimated sap production (ESP) was calculated using the total volume of sap production from four plants multiplied by the number of plants in a meter squared. Fermentable sugar yield (SY) was calculated using ESP and Brix in the following equation: SY $=\mathrm{ESP} \times$ Brix $\times 0.75$ [13]. The four plants that were not pressed and removed of sap provided biomass for the silage samples.

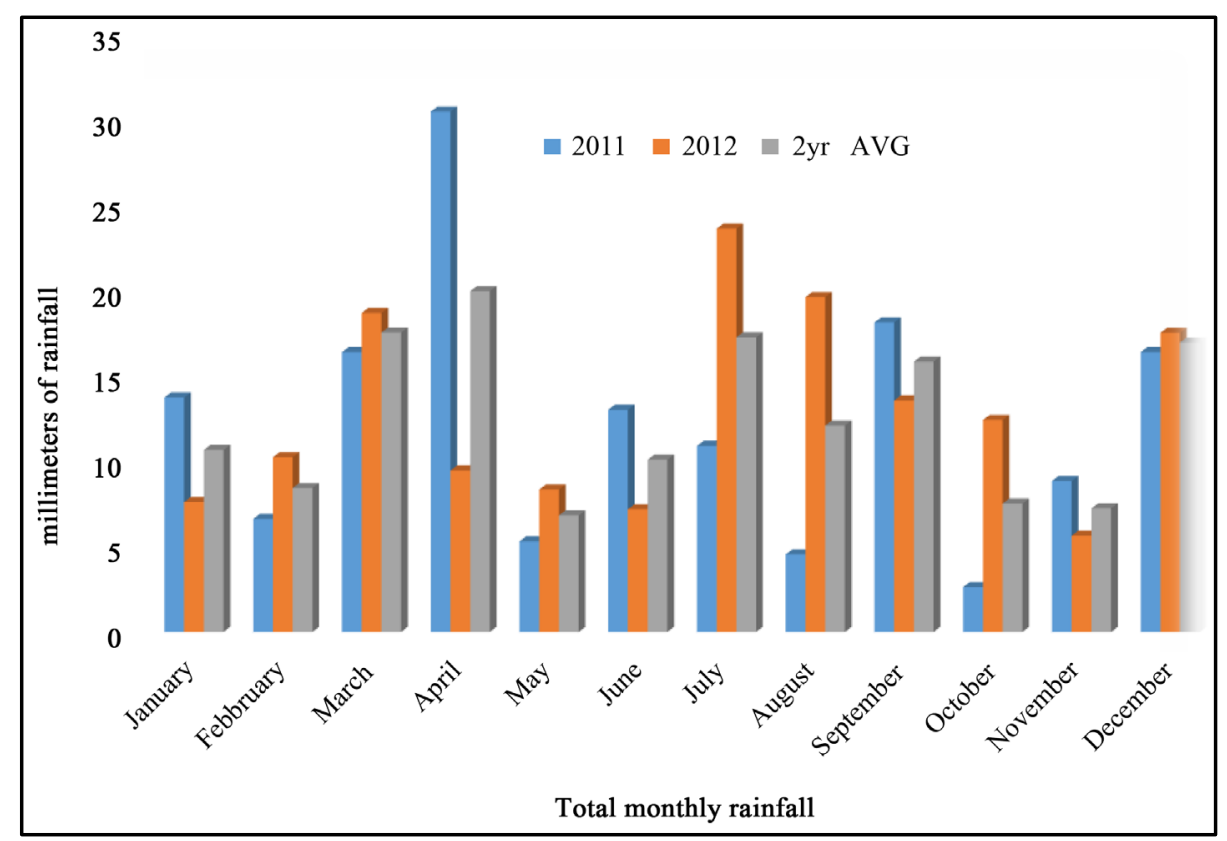

Figure 1. Rainfall data for Starkville, Mississippi in 2011 and 2012 and the average between the two years. 


\subsection{Post-Harvest Treatments}

Post-harvest treatments included silage (samples not pressed), silage from bagasse (BS) and hay samples from each plot. The silage and BS samples were chopped to pieces smaller than $2.54 \mathrm{~cm}$ using hand held pruners before being vacuum sealed in freezer bags. After being vacuum sealed, silage and BS bags were put in black trash bags in stored in an area free of light for 45 days. After the ensiling, process silage samples were re-weighed to retain a wet weight and placed in a force aired oven at $66^{\circ} \mathrm{C}$ until weight remained constant. Hay samples were collected as subsamples from the entire plot harvest and placed in a forced air oven at $66^{\circ} \mathrm{C}$ until weight remained constant. Hay samples were similar in particle size to the silage and BS samples after being chopped in the Winterstieger Cibus S harvester (Winterstieger AG, Ried, Austria). All samples were ground to pass through a 2-mm screen using a Wiley mill (Thomas Scientific, Swedesboro, NJ). Ground samples were then analyzed for fiber quality which includes acid detergent fiber (ADF), neutral detergent fiber (NDF) and crude protein (CP) using Near Infrared Reflectance (NIR) with a Foss 6500 (NIRSystems, Inc., Laurel, ML). Hay samples were analyzed in the grass hay equation while the silage and BS samples were analyzed using the corn silage equation developed by the NIRS Feed and Forage Testing Consortium (Hillsboro, WI).

\subsection{Statistical Analysis}

Data was analyzed using PROC GLM of SAS (SAS Institute Inc., Cary, NC) and mean separation was done using the least significant difference (LSD) at $\infty=0.05$. The analysis for forage yield and SY included main effects of variety, year and the interaction of year $\times$ variety. Fiber quality was analyzed by main effects of variety, treatment, (silage, BS, hay), and interactions of variety $\times$ treatment. Years were analyzed separately for fiber quality and the 2-year average used for reporting.

\section{Results \& Discussion}

\subsection{Biomass Yield}

An interaction between year and variety was significant for forage yield $(P<0.0001)$ and SY $(P=0.0402)$. In 2012 forage yields were increased up to 5 times as much from 2011. Forage yields in 2011 showed varieties Piper and King BMR to have the lowest yields while Pearl Millet, Greengrazer V, and Pace Setter produced the greatest. In 2012 DM yields were greatest in Greengrazer V and Sweet-N-Honey II while Sweet-N-Honey BMR produced the least forage (Table 1). Substantial differences may be contributed to a warm spring and earlier

Table 1. Forage yield from 12 annual warm-season grass varieties from 2011, 2012 and the average between those years.

\begin{tabular}{|c|c|c|c|c|}
\hline \multirow[b]{2}{*}{ Variety } & \multirow[b]{2}{*}{ Species } & \multicolumn{2}{|c|}{ Year } & \multirow[b]{2}{*}{ Avg. } \\
\hline & & 2011 & 2012 & \\
\hline & & \multicolumn{3}{|c|}{$\mathrm{kg} \cdot \mathrm{ha}^{-1}$} \\
\hline Cowvittles & Sorghum & 4409 & 8815 & 7412 \\
\hline Forage King BMR & Sorghum/Sudan & 4404 & 8343 & 7144 \\
\hline Greengrazer V & Sorghum/Sudan & 5579 & 10,913 & 9244 \\
\hline King BMR & Sudangrass & 2458 & 8011 & 5868 \\
\hline Monarch V & Sudangrass & 3572 & 7077 & 5969 \\
\hline Pace Setter & Sorghum/Sudan & 6120 & 8757 & 8338 \\
\hline Pace Setter BMR & Sorghum/Sudan & 3048 & 5416 & 4744 \\
\hline Pearl Millet FSG300 & Millet & 6405 & 6662 & 7324 \\
\hline Piper & Sudangrass & 1391 & 7176 & 4802 \\
\hline Sweeter-N-Honey BMR & Sorghum/Sudan & 2660 & 3852 & 3650 \\
\hline Sweeter-N-Honey II & Sorghum/Sudan & 5160 & 10,586 & 8825 \\
\hline Sweeter-N-Honey II BMR & Sorghum/Sudan & 2625 & 6111 & 4896 \\
\hline Mean & & 3986 & 7643 & 6518 \\
\hline $\mathrm{CV} \%$ & & 20 & 11 & 13 \\
\hline LSD 0.05 & & 1193 & 984 & 1519 \\
\hline
\end{tabular}


planting date. The 2012 trial was planted on May 5, nearly a month and half earlier than the 2011 planting of June 16. Temperatures during May and June of 2012 were adequate for plant growth and rains received during this period contributed to increased growth in the 2012 trial harvested July 9 compared to the 2011 trial which was not harvested until August. Pearl Millet was the only crop that did not utilize the ideal conditions in 2012, producing similar yields both years. Pearl millet was one of the greatest yielders in 2011 but one of the least in 2012. This may be a result of pearl millets drought tolerance ability compared to sorghum and sudangrass. Considering the 2-year average Sweet N Honey II, Greengrazer V and Pace Setter all sorghum/sudangrass hybrids were the only varieties to produce significantly over the mean. Forage yields were similar to variety trials preformed in the area for some sorghum/sudangrass varieties, but less than those preported for sorghum, sudangrass, and pearl millet varieties (12). However, the forage variety trials incorporate a double harvest system possibly increasing yield. A decrease in harvest maturity would likely have a negative effect on fermentable SY.

\subsection{Fermentable Sugar Yield (SY)}

Fermentable sugar yield was greatest in 2011 nearly double that produced in 2012. This was opposite that observed in forage yield where 2012 supplied the prevailing average yield (Table 2). The only sorghum variety, Cowvittles, available in the trial was also the sole entry that produced greater SY in 2012 than in 2011 while still maintaining average forage yields. However, the general decrease in SY in 2012 was an obvious function of biomass yield suggesting that as forage yield increases SY will decrease in sudangrass, millets and sorghum/ sudangrass hybrids. More data utilizing several forage sorghums in a similar trial would aid in explaining this interaction. Over the 2 years, the data in Table 2 presents the three varieties above the mean in SY is Cowvittles, Greengrazer V and Sweet-N-Honey II. The sorghum/sudangrass hybrid Sweet-N-Honey II produced the greatest SY over 2 years and while producing superior forage yields. Varieties that produced the least SY over 2 years include all three sudangrass varieties as well as pearl millet and Sweeter-N-Honey II BMR, Pace Setter BMR. Though BMR type varieties are commonly considered for lignocellulosic conversion [1] and are popular in the cattle industry, this is mainly due to an lower lignin content thus increasing both rumen and bio digestion. In this study only half of the BMR type varieties produced above average SY and same name varieties without the BMR gene had greater SY than their counterparts.

Table 2. Estimated fermentable sugar yield from 12 varieties of summer annuals from harvest in 2011, 2012 and the average of those years.

\begin{tabular}{ccccc}
\hline & & & \multicolumn{2}{c}{ Years } \\
Varieties & Species & 2011 & 2012 & Avg. \\
\cline { 3 - 5 } Cowvittles & & & $\mathrm{kg}^{-h^{-1 \dagger}}$ & \\
\hline Forage King BMR & Sorghum & 381 & 467 & 425 \\
Greengrazer V & Sorghum/Sudan & 435 & 253 & 344 \\
King BMR & Sorghum/Sudan & 491 & 279 & 385 \\
Monarch V & Sudangrass & 73 & 26 & 49 \\
Pace Setter & Sudangrass & 93 & 28 & 61 \\
Pace Setter BMR & Sorghum/Sudan & 417 & 182 & 299 \\
Pearl Millet FSG300 & Sorghum/Sudan & 308 & 148 & 228 \\
Piper & Millet & 243 & 55 & 149 \\
Sweeter-N-Honey BMR & Sudangrass & 73 & 8 & 40 \\
Sweeter-N-Honey II & Sorghum/Sudan & 492 & 133 & 313 \\
Sweeter-N-Honey II BMR & Sorghum/Sudan & 589 & 405 & 497 \\
Mean & Sorghum/Sudan & 361 & 191 & 276 \\
CV\% & & 330 & 182 & 256 \\
LSD 0.05 & & 38 & 40 & 3131 \\
\hline
\end{tabular}

${ }^{\dagger}$ Sugar yield = Juice yield ${ }^{*}$ Brix ${ }^{*} 0.75$. 
Fermentable sugar yields for this trial were generally very low compared to those reported for sweet sorghum. Wortmann et al. [13] reported SY over $3000 \mathrm{~kg} \cdot \mathrm{ha}^{-1}$ for sweet sorghum yields in Nebraska nearly 8 times greater than those produced in this trial. However, the sweet sorghum in that particular trial was delayed until soft dough stage when estimated sugar concentrations are the greatest [14] compared to the forage harvest regiment ( $50 \%$ boot stage) implemented in the current study.

\subsection{Forage Quality}

In 2011 and 2012 ADF, NDF, and CP was affected by treatment and variety main affects but no interaction was significant between treatment and variety (Table 3). An apparent interaction was evident between 2011 and 2012 but this was assumed to be the function of forage yield and SY differences already discussed.

In 2011 silage fiber quality actually increased after the removal of sap with higher CP and lower ADF and NDF values than both the hay and silage samples. Alternatively, in 2012 the same trend was not evident. Hay and post crushed silage (BS) were similar in quality for both NDF and ADF values but BS samples had slightly lower CP values (Figure 2). One explanation for the strong difference in year is that the 2011 BS and silage samples were not chopped up resulting in relatively poor bag sealing and consequently poor silage. Samples from 2012 ensiled well with very few bag bloating due to samples being manually chopped with pruners to ensure proper sealage and mechanically freeing more sugars. Results from 2012 are what was expected considering the removal of most of the soluble sugars. In general BS samples ensiled in 2012 had lower fiber quality than conventional silage but similar in almost all aspects to forage cut for hay. Quality was also affected by year as a result of increased forage yields received in 2012 compared to 2011. With the exception of CP values fiber fractions were similar to those reported in the warm-season forage variety bulletin in Starkville, MS. which included many of the same varieties (12).

Varieties displayed a minimal but still significant difference for fiber quality in hay and silage samples but BS samples preformed similarly across variety. Varieties like Greengrazer V and Cowvittles that yielded above average SY decreased in quality when being utilized as hay. This trend would be expected considering ensiling maintains better quality in forages than when curing for hay so varieties with relatively good quality will de-

Table 3. Hay, silage from bagasse and silage biomass quality described using ADF, NDF, and CP for 12 annual warm-season grasses.

\begin{tabular}{ccccccccccc}
\hline Variety & \multicolumn{3}{c}{ Hay } & \multicolumn{3}{c}{ Bagasse Silage } & \multicolumn{3}{c}{ Silage } \\
& ADF & NDF & CP & ADF & NDF & CP & ADF & NDF & CP \\
\cline { 2 - 8 } & & & & & $\mathrm{g} \cdot \mathrm{kg}^{-1}$ & & & \\
Cowvittles & 430 & 720 & 90 & 400 & 680 & 90 & 340 & 600 & 100 \\
Forage King BMR & 390 & 660 & 120 & 380 & 670 & 100 & 330 & 590 & 100 \\
Greengrazer V & 410 & 660 & 110 & 400 & 660 & 100 & 330 & 570 & 90 \\
King BMR & 400 & 690 & 110 & 410 & 670 & 90 & 390 & 630 & 100 \\
Monarch V & 390 & 670 & 90 & 410 & 670 & 100 & 350 & 580 & 100 \\
Pace Setter & 380 & 670 & 110 & 420 & 670 & 90 & 380 & 620 & 90 \\
Pace Setter BMR & 420 & 700 & 100 & 390 & 660 & 100 & 340 & 590 & 110 \\
Pearl Millet FSG300 & 390 & 680 & 110 & 400 & 670 & 80 & 340 & 550 & 110 \\
Piper & 410 & 710 & 100 & 430 & 700 & 90 & 380 & 620 & 100 \\
Sweeter-N-Honey BMR & 390 & 660 & 110 & 380 & 670 & 110 & 340 & 570 & 110 \\
Sweeter-N-Honey II & 400 & 670 & 110 & 420 & 710 & 80 & 360 & 610 & 90 \\
Sweeter-N-Honey II BMR & 410 & 700 & 90 & 380 & 660 & 110 & 340 & 590 & 110 \\
Mean & 400 & 680 & 110 & 400 & 670 & 90 & 350 & 590 & 100 \\
CV\% & 3 & 3 & 13 & 8 & 8 & 18 & 6 & 5 & 11 \\
LSD 0.05 & 20 & 30 & NS & NS & NS & NS & 30 & 40 & 20 \\
\hline
\end{tabular}




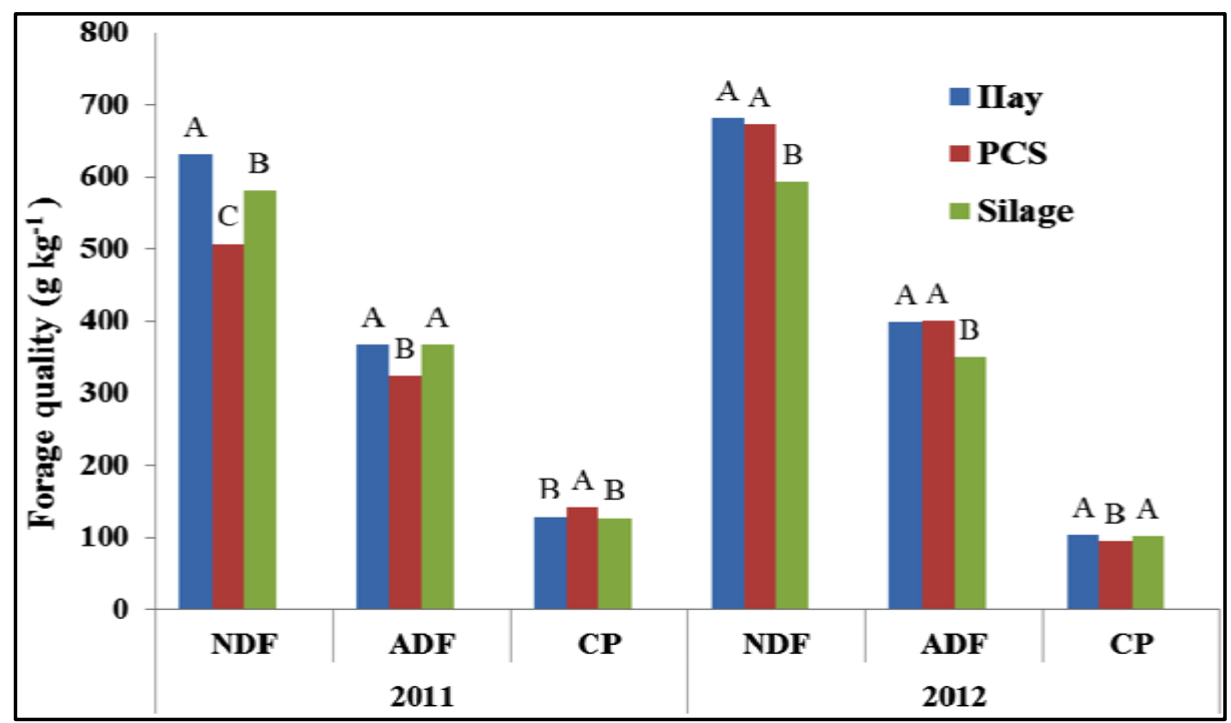

Figure 2. Acid Detergent Fiber (ADF), Neutral Detergent Fiber (NDF) and Crude Protein (CP) values of annual warm-season grasses harvested as hay, silage and bagasse silage (BS) for harvest in 2011 and 2012. Similar letters between bars for each fiber fraction type in each year was not different when $P=0.05$.

crease more as the hay process progresses. Variety differences in BS samples should also be expected; but different concentrations of sap removal in plants with larger stalks may have aided in mitigating this effect of variety on forage quality.

\section{Conclusion}

Forage type sorghums and sorghum/sudangrass hybrids produced significantly less SY than typical sweet sorghum yields reported on varieties commonly considered for their sap production. The only forage sorghum variety in the trial performed well with the greatest SY while still producing good forage yield for subsequent silage. It is apparent however, that SY and forage yield will not be easily compromised in a dual purpose system as increased biomass yield usually had a negative effect on SY. However, if a sap industry is developed and pressing machinery included as a part of the silage process then forage quality will only be slightly decreased. Sweet sorghums for sap production have already been assessed in Mississippi and determined to not be profitable, but this was considering sap to be the only potential income in the system. The potential for silage from bagasse as the main product of an agricultural system may offset these cost. More research should be done addressing harvest maturity for the most profitable compromise between SY and biomass yield. In addition, an economic analysis is needed to evaluate the amount of SY needed with the value of the silage to make such system profitable.

\section{Acknowledgements}

Thanks to Isaac Pickett, Daniel Moore, Dereck Mc Cain, and Jonathan Norton for their help with data collection and processing.

"This material is based upon work performed through the Sustainable Energy Research Center at Mississippi State University and is supported by the Department of Energy under Award Number DE-FG3606GO86025.”

Disclaimer: "This report was prepared as an account of work sponsored by an agency of the United States Government. Neither the United States Government nor any agency thereof, nor any of their employees, makes any warranty, express or implied, or assumes any legal liability or responsibility for the accuracy, completeness, or usefulness of any information, apparatus, product, or process disclosed, or represents that its use would not infringe privately owned rights. Reference herein to any specific commercial product, process, or service by trade name, trademark, manufacturer, or otherwise does not necessarily constitute or imply its endorsement, recommendation, or favoring by the United States Government or any agency thereof. The views and opinions 
of authors expressed herein do not necessarily state or reflect those of the United States Government or any agency thereof."

\section{References}

[1] Corredor, D.Y., Salazar, J.M., Hohn, K.L., Bean, S., Bean, B. and Wang, D. (2008) Evaluation and Characterization of Forage Sorghum as Feedstock for Fermentable Sugar Production. Applied Biochemistry and Biotechnology, 158, 164179. http://dx.doi.org/10.1007/s12010-008-8340-y

[2] Vermerris, W., Erickson, J., Wright, D., Newman, Y. and Rainbolt, C. (2011) Production of Biofuel Crops in Florida: Sweet Sorghum. University of Florida IFAS Extension, Gainesville.

[3] Smith, G.A. and Buxton, D.R. (1993) Temperate Zone Sweet Sorghum Ethanol Production Potential. Bioresource Technology, 43, 73-75. http://dx.doi.org/10.1016/0960-8524(93)90086-Q

[4] Smith, G.A., Bagby, M.O., Lewellan, R.T., Doney, D.I., Moore, P.H., Hills, F.J., Campbell, L.G., Hogaboam, G.J., Coe, G.E. and Freeman, K. (1987) Evaluation of Sweet Sorghum for Fermentable Sugar Production Potential. Crop Science, 27, 788-793. http://dx.doi.org/10.2135/cropsci1987.0011183X002700040037x

[5] Lueschen, W.E., Putman, D.H., Kanne, B.K. and Hoversted, T.R. (1991) Aromomic Practices for Production of Ethanol from Sweet Sorghum. Journal of Production Agriculture, 4, 619-625. http://dx.doi.org/10.2134/jpa1991.0619

[6] Linton, J.A., Miller, J.C., Little, R.D., Petrolia, D.R. and Coble, K.H. (2011) Economic Feasibility of Producing Sweet Sorghum as an Ethanol Feedstock in the Southeastern United States. Biomass \& Bioenergy, 35, 3050-3057. http://dx.doi.org/10.1016/j.biombioe.2011.04.007

[7] Bing-Zhi, L., Balan, V., Yuan, Y. and Dale, B.E. (2010) Process Optimization to Convert Forage and Sweet Sorghumbagasse to Ethanol Based on Ammonia Fiber Expansion (AFEX) Pretreatment. Bioresource Technology, 101, 12851292. http://dx.doi.org/10.1016/j.biortech.2009.09.044

[8] Houx, J.H., Roberts, C.A. and Fritshci, F.B. (2013) Evaluation of Sweet Sorghum Bagasse as an Alternative Livestock Feed. Crop Science, 53, 1784-1790. http://dx.doi.org/10.2135/cropsci2012.03.0190

[9] Caielli, E.L. (1986) Case Study: Brazil, Sugarcane as Feed. In: Sansourcy, R., et al., Eds., Sugarcane as Feed, Animal Production and Health Paper No. 72, Rome, 1-13.

[10] Lemus, R. (2008) Forage Production Survey in Mississippi. Mississippi State University Extension Service. Unpublished Data.

[11] Edwards, N.C., Elmore, R., Hovermale, C., Ingram, D., Ivy, R., Johnson, B., Lang, D. and Watson, V. (1991) Performance of Warm Season Forage Crop Varieties 1988-1990. Mississippi Agricultural and Forestry Experiment Station, Inf. Bull., Starkville, 192.

[12] White, J.A., Lemus, R., Saunders, R. and Fritzgerald, L. (2014) Mississippi Warm-Season Forage Cropvariety Trials 2013. Mississippi Agriculture and Forestry Experiment Station, Bull., Starkville, 483.

[13] Wortmann, C.S., Liska, A., Ferguson, R.B., Lyon, D.J. and Klien, R.N. (2010) Dryland Performance of Sweet Sorghum and Grain Crops for Biofuel in Nebraska. Agronomy Journal, 102, 319-326. http://dx.doi.org/10.2134/agronj2009.0271

[14] Broadhead, D.M. (1974) Effect of Planting Date and Maturity on Juice Quality of Rio Sweet Sorghum. Agronomy Journal, 64, 389-390. http://dx.doi.org/10.2134/agronj1972.00021962006400030039x 
Scientific Research Publishing (SCIRP) is one of the largest Open Access journal publishers. It is currently publishing more than 200 open access, online, peer-reviewed journals covering a wide range of academic disciplines. SCIRP serves the worldwide academic communities and contributes to the progress and application of science with its publication.

Other selected journals from SCIRP are listed as below. Submit your manuscript to us via either submit@scirp.org or Online Submission Portal.
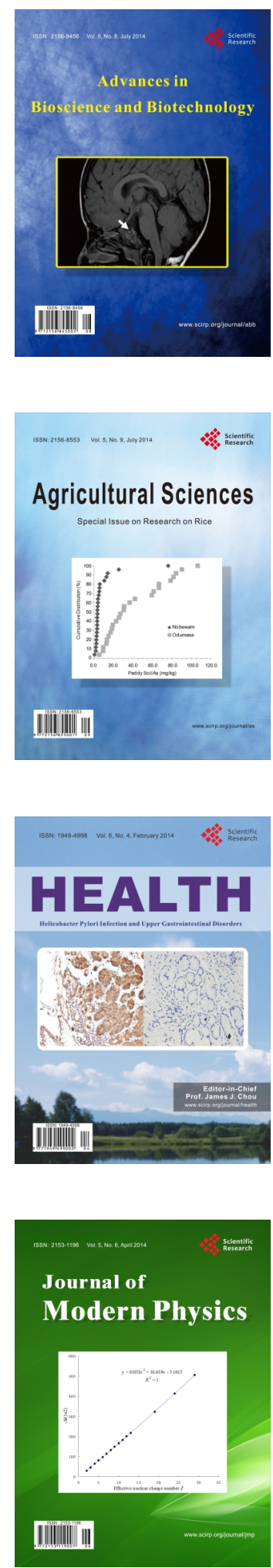
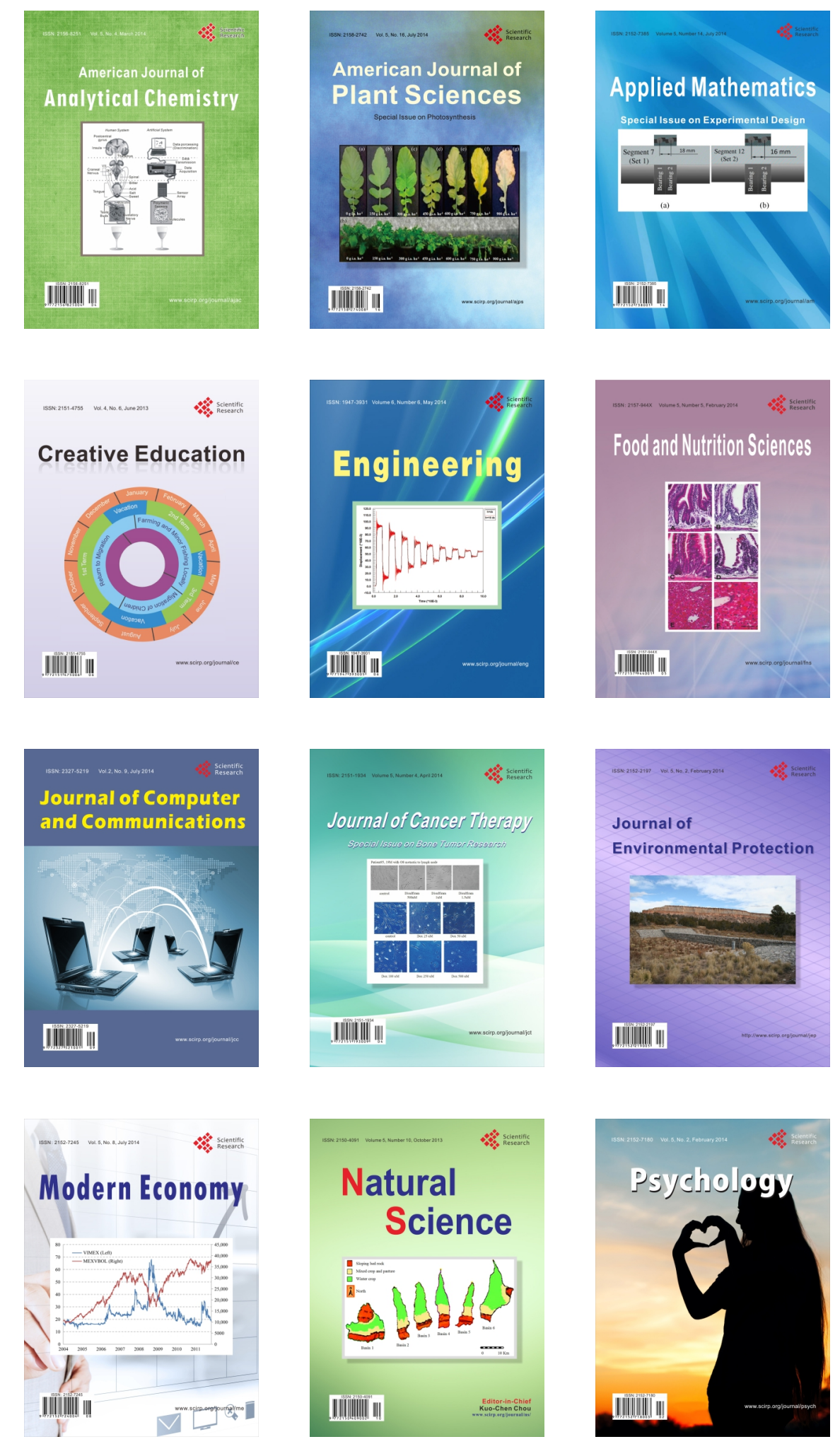